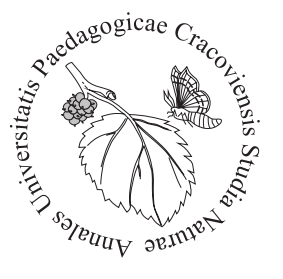

Annales Universitatis Paedagogicae Cracoviensis

Studia Naturae, 3: 22-37, 2018, ISSN 2543-8832

DOI: $10.24917 / 25438832.3 .2$

Terézia Beck ${ }^{\star}$, Ján Gáper², Martin Šebesta², Svetlana Gáperová1

'Faculty of Natural Sciences, Matej Bel University, Tajovského 40, 97401 Banská Bystrica, Slovak Republic, *terezia.gasparcova@umb.sk ${ }^{2}$ Faculty of Ecology and Environmental Sciences, Technical University in Zvolen, T. G. Masaryka 24, 96063 Zvolen, Slovak Republic

${ }^{3}$ Faculty of Sciences, University of Ostrava, Chittussiho 10, 71000 Ostrava, Czechia

\title{
Host preferences of wood-decaying fungi of the genus Ganoderma in the urban areas of Slovakia
}

Introduction

Ganoderma P. Karst. 1881 (Basidiomycota, Polyporales) is a cosmopolitan genus (Richter et al., 2015) with the greatest diversity in the tropical regions (Ryvarden, Melo, 2014). Fungi of this genus cause white rot of living or dead deciduous and coniferous trees of the wide range of species worldwide (Schwarze, Ferner, 2003; Bernicchia, 2005; Ryvarden, Melo, 2014). The species of Ganoderma, especially Ganoderma lucidum complex, are also known due to their various medicinal properties (Zhou et al., 2015).

The basidiocarps of these polypores grow annually or can be perennial, sessile, or stipitate, with matte or a laccate pileus surface, cream to dark purplish-brown-coloured context and creamed-coloured pore surface, brownish after touching (Ryvarden, Melo, 2014). The genus Ganoderma is characterised by ovoid, echinulate basidiospores with a truncate apex, two layered walls and interwall pillars between endosporium and exosporium (Ryvarden, 1991; Moncalvo, 2000; Ryvarden, Melo, 2014).

The Ganoderma species that occur in Europe are G. adspersum (Schulzer) Donk, G. applanatum (Pers.) Pat., G. carnosum Pat., G. lucidum (Curtis) P. Karst., G. pfeifferi Bres., G. resinaceum Boud., and G. valesiacum Boud. (Sokól, 2000; Bernicchia, 2005; Papp, Szabó 2013; Ryvarden, Melo, 2014). The presence of all these species was also recorded in Slovakia (Gáper, 1998; Gáperová, 2001; Gašparcová et al., 2017a). The interspecific genetic diversity of Ganoderma species occurring in Slovakia was also studied by PCR-RFLP analysis of ITS nrDNA and with newly applied method MALDI-TOF MS (Pristaš, Gáperová, 2001; Gašparcová et al., 2017b; Pristaš et al., 2017).

Host preferences of European Ganoderma species were analysed by several authors. G. adspersum has synanthropic character of distribution (Kotlaba, 1984; 
Gáper, 1998; Sokół, 2000; Gáperová, 2001; Kotlaba, Pouzar, 2009a; Papp, Szabó, 2013). In southern and warmer regions, it also occurs in forests (Kotlaba, Pouzar, 2009a). In Europe, it was recorded on 43 genera of trees (Breitenbach, Kränzlin, 1986; Ryvarden, Gilbertson, 1993; Bernicchia, 2005; Ryvarden, Melo, 2014).

G. applanatum is the most common European species known as the "artists fungus” (Sokół, 2000; Ryvarden, Melo, 2014). It grows mostly in forests (Kotlaba, 1984; Sokół, 2000; Papp, Szabó, 2013) and rarely in urban areas (Gáperová, 2001). In Europe, it was recorded on 35 genera of trees (Breitenbach, Kränzlin, 1986; Bernicchia, 2005; Ryvarden, Melo, 2014).

G. resinaceum often grows in urban areas such as parks and gardens, near roads, etc. (Kotlaba, 1984; Gáper, 1998; Sokół, 2000; Gáperová, 2001; Kotlaba, Pouzar, 2009b), but in warmer regions it also occurs in forest environment (Kotlaba, Pouzar, 2009a). It prefers hosts of the genus Quercus, but it is known from many other deciduous trees (Kotlaba, 1984; Breitenbach, Kränzlin, 1986; Bernicchia, 2005; Ryvarden, Melo, 2014).

G. pfeifferi is typical synanthropic species that prefers old beeches in parks, but in southern Europe, in Denmark (Sokól, 2000) and Hungary (Papp, Szabó, 2013) follows occurence of old beech forests. However, it was also noted on Acer, Aesculus, Fraxinus, Prunus, Quercus and Ulmus (Bernicchia, 2005; Ryvarden, Melo, 2014).

G. lucidum is the type species of the genus (Richter et al., 2015) and it belongs to the G. lucidum complex (Zhou et al., 2015). It often colonises old deciduous trees in parks and botanical gardens, but it occurs mainly in forests (Sokól, 2000; Bernicchia, 2005). Basidiocarps of G. lucidum grow mostly on oaks, but also on other trees (Kotlaba, 1984; Tortić, 1985; Sokół, 2000; Karadelev et al., 2008; Papp, Szabó, 2013; Ryvarden, Melo, 2014). In Europe, it grows on 24 woody plants genera (Bernicchia, 2005; Ryvarden, Melo, 2014).

G. carnosum belongs together with G. lucidum to the 'G. lucidum complex' (Ryvarden, Melo, 2014). Similar to G. lucidum, it occurs mainly in forest environment, but it can also appear in parks or botanical gardens (Sokół, 2000; Gáperová, 2001). It grows usually on conifers (Ryvarden, Melo, 2014) mainly Abies alba Mill. (Kotlaba, 1984; Bernicchia, 2005). In Europe, it colonises trees of 10 genera (Breitenbach, Kränzlin, 1986; Bernicchia, 2005; Ryvarden, Melo, 2014).

G. valesiacum is central European species that occurs at higher altitudes in natural coniferous forests (Plank, Wolkinger, 1981; Kotlaba, 1984; Sokól, 2000; Bernicchia, 2005; Ryvarden, Melo, 2014). It is very rare European species and there are no data on the synanthropic character of this species (Sokól, 2000). It was recorded on Larix (Kotlaba, 1984; Sokó1, 2000; Bernicchia, 2005; Ryvarden, Melo, 2014) and probably on Picea abies (L.) H.Karst. (Kotlaba, 1984; Sokół, 2000). 
There are only few studies focusing on distribution of fungi of this genus in Slovakia and on their host preferences. Most of them confirm the presence of this genus in urban areas (Kotlaba, 1984; Gáper, 1998; Gáperová, 2001; Boleková, Sliacka, 2015). A more comprehensive analysis of Ganoderma's host range in forests in Slovakia was presented by Gašparcová et al. (2017a). The aim of the present study was to identify the host preferences of the species of this genus occurring in the urban areas of Slovakia, and the analysis of the location of basidiocarps on the colonised trees.

\section{Material and methods}

Data on the occurrence, host preferences, and topology of Ganoderma basidiocarps on the colonised trees/wood were obtained by field research and from the information given for herbarium specimens located in Slovak National Museum - Natural History Museum in Bratislava and National Museum - Natural History Museum in Prague (Czechia). The field research of authors was carried out in the period of 1989-2017 in the urban areas of Slovakia. The basidiocarps obtained during field research were deposited in the Herbarium of the Department of Biology and Ecology of the Faculty of Natural Sciences, Matej Bel University, Banská Bystrica, Slovakia. All basidiocarps used in the present study were collected in the districts Bánovce nad Bebravou, Banská Bystrica, Banská Štiavnica, Bardejov, Bratislava, Čadca, Detva, Dunajská Streda, Galanta, Hlohovec, Kežmarok, Komárno, Košice, Krupina, Levice, Levoča, Liptovský Mikuláš, Lučenec, Malacky, Martin, Michalovce, Myjava, Nitra, Nové Mesto nad Váhom, Nové Zámky, Pezinok, Pieštany, Poltár, Poprad, Považská Bystrica, Prešov, Prievidza, Rožňava, Ružomberok, Senica, Spišská Nová Ves, Stará Lubovňa, Trebišov, Trenčín, Trnava, Velký Krtíš, Vranov nad Toplou, Zlaté Moravce, Zvolen, Žiar nad Hronom and Žilina. All obtained data were recorded in a database (Gáperová, Krát$\mathrm{ka}, 2002$ ) that is currently based on a total of 34 input data divided into 5 categories: I - characteristics of tree, II - characteristics of localities, III - characteristics of fungus, IV - general data (in relation to a specific finding), V - vitality of tree. The database is connected with digital maps in the GIS environment (Gáperová, Krátka, 2002; 2003; Krátka et al., 2004).

Basidiocarps were determined using scientific mycological literature (Breitenbach, Kränzlin, 1984; Ryvarden, 1991; Sokół, 2000; Bernicchia, 2005; Antonín, 2006; Holec et al., 2012; Ryvarden, Melo, 2014). Microscopic studies were performed with the use of a MOTIC microscope (Motic Company, Germany), on preparations mounted in $5 \% \mathrm{KOH}$.

The topology of basidiocarps was evaluated for each recorded species separately. Places of the occurrence of basidiocarps on trees were divided into the following categories: stump, root swelling, dead trunk base, dead standing/laying trunk, living trunk 
base, living trunk, others. The category 'others' includes some parts of host woody plants that do not belong to the previous categories (e.g., tree branch, dead wood) or in the case of herbarium specimens for which places of basidiocarps occurrence were not recorded.

For nomenclature of fungi, The Index Fungorum (Cooper, Kirk, 2018) database was followed. For nomenclature of woody plants, the checklist by Marhold and Hindák (1998) and The International Plant Names Index database (IPNI, 2012) were followed.

\section{Results and discussion}

A total of 263 collections of basidiocarps were analysed to detect host preferences of fungi of the genus Ganoderma in urban areas of Slovakia (Appendix 1 - Tab. 1). We confirmed the presence in urban areas of Slovakia all the species recorded in the country, namely Ganoderma applanatum, G. adspersum, G. carnosum, G. lucidum, G. pfeifferi, G. resinaceum and G. valesiacum.

We found out that Ganoderma adspersum is the most common species of the genus Ganoderma occurring in urban areas of Slovakia (Fig. 1). It was recorded on 24 species of host woody plants (Appendix 1 - Tab. 1). A wide range of hosts is associated with the synanthropic character of this species in our country. The basidiocarps most often occurred on Aesculus hippocastanum L. (18\% of all findings) and Tilia cordata Mill. (17\% of all findings). Similar to our results, Gáperová (2001) recorded G. adspersum mainly on the introduced tree A. hippocastanum and the native T. cordata in urban environments of Slovakia. Moreover, fungi also grew on other planted non-native trees, mainly Gleditsia triacanthos L. (8\%), Prunus serrulata Lindl. (3\%) and Robinia pseu-

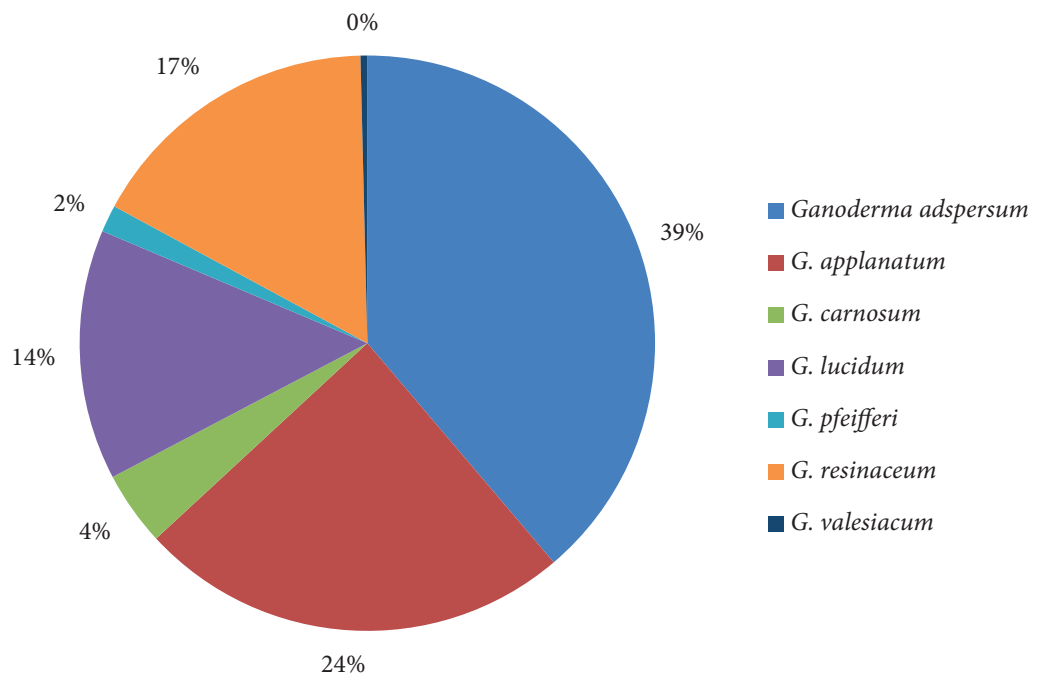

Fig. 1. Representation of species of the genus Ganoderma in urban areas of Slovakia 
doacacia L. (3\%). Our findings have not proved oaks as the most common substrate/ host that was recorded by some authors (Kotlaba, 1984; Tortić, 1985; Gáper, 1998; Papp, Szabó, 2013). However, in the forest environments of Slovakia, G. adspersum was found to grow mainly on Quercus robur L. (Gašparcová et al., 2017a). According to Kotlaba and Pouzar (2009a), G. adspersum is a parasitic species often found on planted trees in urban areas, because inner parts of the forest complexes of northern and northwest European countries are too cold. However, in the southern warmer climatic regions of Europe, including Moravia (Czechia) and Slovakia, G. adspersum also colonises native trees in forests (Kotlaba, Pouzar, 2009a). Our research confirms its synanthropic character and frequent occurrence on non-native trees (39\% of all findings) in urban areas, which was also realised by other authors (Kotlaba, 1984; Gáper, 1998; Sokół, 2000; Gáperová, 2001; Kotlaba, Pouzar, 2009a; Papp, Szabó, 2013). The basidiocarps of $G$. adspersum were found growing mainly on the base and along the living trunk, and also saprotrophically on stumps (Fig. 2). It corresponds well to the published data (Breitenbach, Kränzlin, 1986; Sokół, 2000; Bernicchia, 2005; Ryvarden, Melo, 2014). In the forests of Slovakia, it was recorded mainly on the trunk base of host trees (Gašparcová et al., 2017a).

G. applanatum is often misidentified as G. adspersum (Fig. 3), but G. applanatum has smaller basidiospores, paler context, tubes layers separated by thin layers of the context and often attacked by larvae of Agathomya wankowici Schnabl. (Sokół, 2000; Ryvarden, Melo, 2014). In urban areas of Slovakia, G. applanatum was recorded on 18 species of host trees, mostly deciduous (Appendix 1 - Tab. 1). Over $45 \%$ of records come from decomposing wood of different hosts. In our study, we found $9 \%$ of all records on European beech. Other studies confirm its frequent occurrence on Fagus spp. (Kotlaba, 1984; Tortić, 1985; Gáper, 1998; Sokól, 2000; Karadelev et al., 2008; Papp, Szabó, 2013). In the forests of Slovakia, G. applanatum was also found growing predominantly on Fagus sylvatica L. (38\% off all findings). However, compared to urban areas, it was recorded only on 11 species of host trees in forests (Gašparcová et al., 2017). Although more records of this species are known from the forest environment (Gašparcová et al., 2017), G. applanatum is the second most widespread species in urban areas of Slovakia (Fig. 1). We cannot confirm that it grows rarely in urban environments, as reported by Gáperová (2001). However, according to Sokół (2000), G. applanatum occurs in towns more often than typical synanthropic species. In urban areas of Slovakia, G. applanatum was recorded mainly on stumps and the living trunks of host trees (Fig. 2). Some authors also reported that G. applanatum decomposes mainly stumps and dead trunks of deciduous trees, rarely of conifers. It can also colonise living trees, mostly the bases of the trunks (Sokół, 2000; Bernicchia, 2005; Ryvarden, Melo, 2014). In the forests of Slovakia, it was found to grow mainly on trunks and less often on stumps (Gašparcová et al., 2017). 


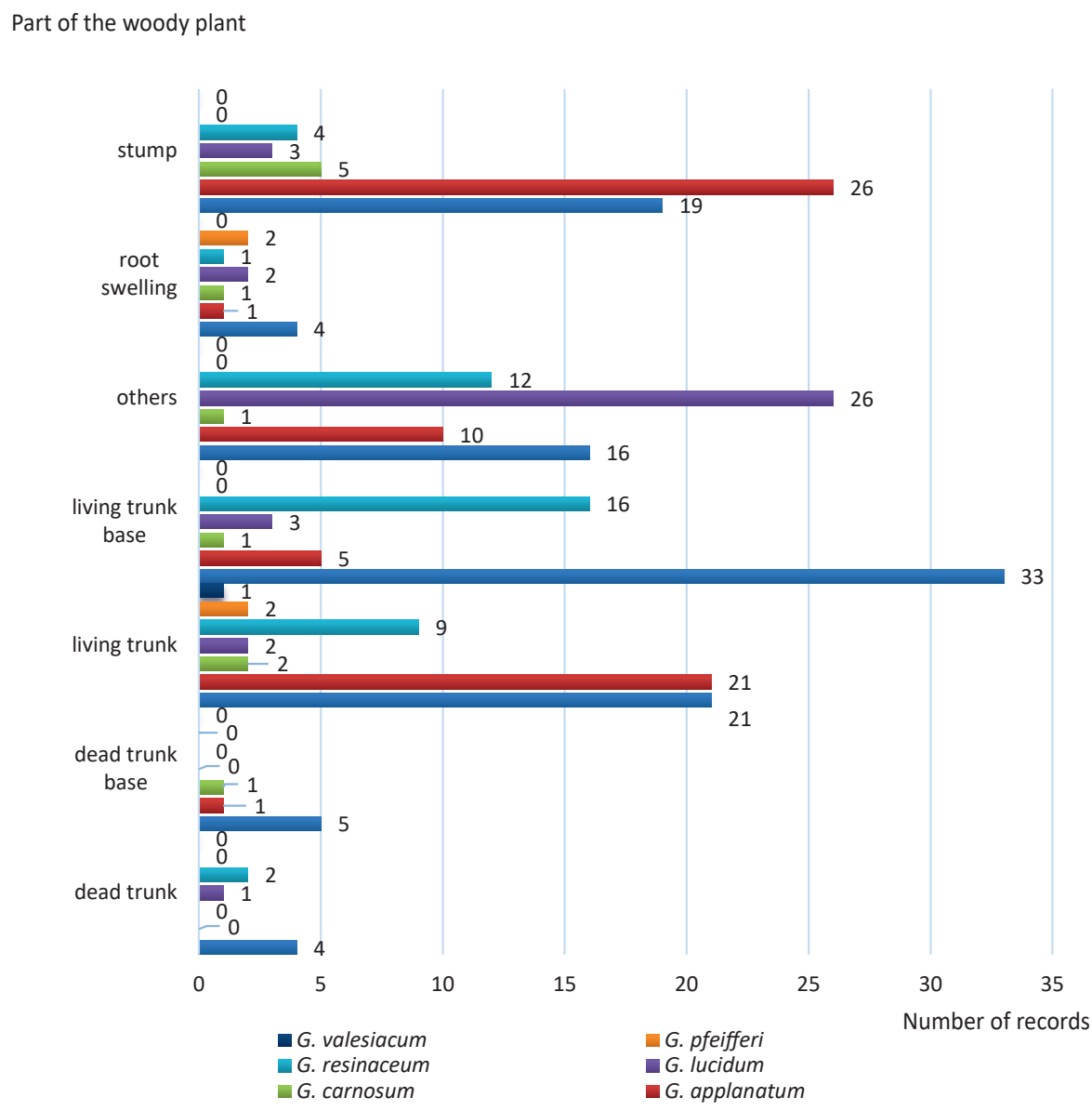

Fig. 2. Topology of the basidiocarps of Ganoderma spp. on host trees

The laccate species G. carnosum was recorded only on 5 genera of host trees (Appendix 1 - Tab. 1). It is a rare species ( $4 \%$ of all records) in the urban areas of Slovakia (Fig. 1). We found out that G. carnosum grew on a decomposing wood (mostly of unknown trees - more than half of all findings). Our results do not confirm published data that it colonises mainly Abies alba Mill. (Kotlaba, 1984; Tortić, 1985; Breitenbach, Kränzlin, 1986; Sokół, 2000; Bernicchia, 2005; Karadelev et al., 2008; Ryvarden, Melo, 2014); however, in the forest ecosystems of Slovakia, it was recorded predominantly on this tree species (Gašparcová et al., 2017). We recorded one new deciduous host tree, Tilia, that has not yet been mentioned in the literature. We found G. carnosum growing saprotrophically mainly on stumps (Fig. 2), which confirms the information found in the literature (Bernicchia, 2005).

The species of G. lucidum and G. carnosum are very similar and difficult to distinguish (Papp, Szabó, 2013), but G. carnosum has larger basidiocarps with darker to blackish pilear surface, and wider spores, and it prefers coniferous trees (Sokól, 2000; 
Ryvarden, Melo, 2014). G. lucidum was recorded on 4 species of host woody plants (Appendix 1 - Tab. 1), although most data do not specify trees species (65\% of all findings). Our results confirm the most common occurrence of this fungus on oaks ( $16 \%$ of all findings) as reported earlier by some authors (Kotlaba, 1984; Tortić, 1985; Sokól, 2000; Karadelev et al., 2008; Papp, Szabó, 2013; Ryvarden, Melo, 2014). We recorded 1 new species of the host tree - Armeniaca vulgaris Lam. The topology of G. lucidum basidiocarps was not recorded in most cases. In addition, it grew in approximately the same amount on stumps, living trunk bases, living trunks, and root swellings (Fig. 2), which partially confirms data presented by Sokół (2000), who stated that it grows on trunk and roots of hardwoods. However, our results do not confirm that G. lucidum grows predominantly saprotrophically, as some authors reported (Sokół, 2000; Bernicchia, 2005; Ryvarden, Melo, 2014). More data on the topology of basidiocarps are needed to draw more precise conclusions.

G. pfeifferi can be often confused with G. adspersum due to several similar features of basidiocarps (Sokól, 2000), but G. pfeifferi has the wrinkled and cracked resinous pilear layer and wider basidiospores (Sokół, 2000; Ryvarden, Melo, 2014). In the urban areas, we recorded G. pfeifferi only 4 times on 3 host species, mainly on Fagus sylvatica (Appendix 1 - Tab. 1). Other studies confirm the occurrence predominantly on beeches (Kotlaba, 1984; Tortić, 1985; Sokól, 2000; Papp, Szabó, 2013; Ryvarden, Melo, 2014). Our results do not show the occurrence of G. pfeifferi on conifers, although Szczepkowski and Konsenczjusz (2006) reported it was probably recorded on Abies sp. We also found 1 new host species for this fungus - Tilia platyphyllos Scop. In the forests of Slovakia, there are a few records of G. pfeifferi basidiocarps, mainly on Fagus sylvatica (Gašparcová et al., 2017a). G. pfeifferi was found to grow in the same number on stumps and paraswitically on the base of trunks (Fig. 2). The occurrence on living trunk base confirms published data (Bernicchia, 2005; Ryvarden, Melo, 2014).

G. resinaceum can be confused with G. lucidum and G. pfeifferi, but G. lucidum has not resinous layer on the crust (Ryvarden, Melo, 2014), its basidiospores have a much coarser ornamentation, and it always forms a stem (Kotlaba, Pouzar, 2009b). G. pfeifferi has wider spores and a darker context (Ryvarden, Melo, 2014). G. resinaceum is the third most widespread Ganoderma species in the urban areas of Slovakia (Fig. 1). It was found growing on 15 species of host trees (Appendix 1 - Tab. 1), mainly on Quercus cerris L. (23\% of all records), which confirms published data (Kotlaba, 1984; Tortić, 1985; Sokół, 2000; Bernicchia, 2005; Papp, Szabó, 2013; Ryvarden, Melo, 2014). Our data prove the synanthropic character of the distribution of G. resinaceum and its rare occurrence in forests (Kotlaba, 1984; Gáper, 1998; Sokół, 2000; Gáperová, 2001; Kotlaba, Pouzar, 2009b). We found that G. resinaceum has various topologies of basidiocarps, but its basidiocarps are formed mainly on the living trunk base (Fig. 2). 


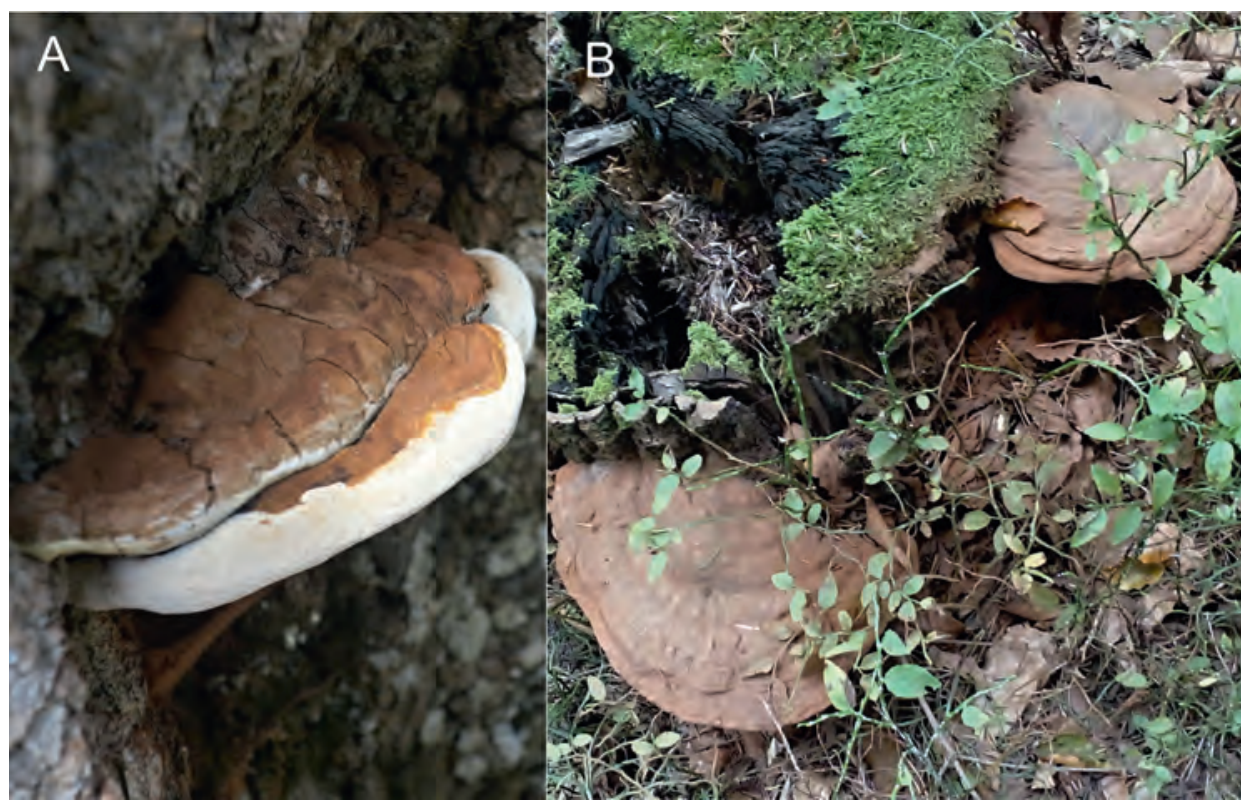

Fig. 3. Ganoderma adspersum (Schulzer) Donk on Tilia cordata Mill. in Trenčianske Teplice (northwestern Slovakia) - A (Photo. S. Gáperová), and Ganoderma applanatum (Pers.) Pat. on Salix caprea L. in Špania Dolina (central Slovakia) - B (Photo. M. Šebesta)

Our results confirm that G. resinaceum grows rather parasitically on the base of trunks (Breitenbach, Kränzlin, 1986; Bernicchia, 2005; Ryvarden, Melo, 2014) than saprotrophically on dead trunks or stumps (Sokól, 2000).

Ganoderma valesiacum can be misidentified as G. lucidum or G. carnosum. It differs from them with very short or rudimentary stipe and often cracked laccate crust exposing white context (Sokól, 2000; Ryvarden, Melo, 2014). However, the taxonomic status of G. valesiacum is uncertain (unclear relationships to G. lucidum and G. carnosum) and sequencing is needed to solve this problem (Ryvarden, Melo, 2014). In the urban areas of Slovakia, we recorded this species on Larix sp. (only 1 record - Fig. 1); although, Sokół (2000) reported that no data on the synanthropic character of this species exist. In the forests of Slovakia, it was also recorded on Larix (Gašparcová et al., 2017a). It confirms published data that G. valesiacum is a very rare European species known from Larix (Plank, Wolkinger, 1981; Kotlaba, 1984; Sokół, 2000; Bernicchia, 2005; Ryvarden, Melo, 2014). G. valesiacum basidiocarps were growing on the living trunk of host tree (Fig. 2), but, as some authors reported, it to grow saprotrophically on the stumps and logs of Larix (Kotlaba, 1984; Sokół, 2000; Bernicchia, 2005; Ryvarden, Melo, 2014), since it was found in the forests of Slovakia (Gašparcová et al., 2017a). 
In the urban areas of Slovakia, we recorded all 7 European Ganoderma species. The most common species is G. adspersum. Most often, it colonised non-native Aesculus hippocastanum and native Tilia cordata (but not Quercus). It grows mostly at the base and along the living trunk and saprotrophically on stumps. G. applanatum is the second most widespread species in the urban areas of Slovakia. It was found mainly on a decomposing wood of unidentified trees and also on beeches. It grows mostly on the stumps, and on the living trunks of host trees. G. resinaceum is the third most widespread in the urban areas of Slovakia. It grows mainly on Quercus. It was recorded mainly on the living trunk base. G. carnosum was recorded only once on Abies alba. It grows saprotrophically, mainly on the stumps. G. lucidum was recorded on a total of 4 species of host woody plants and mostly on oaks. According to available data (in most cases have not been noticed), it grows on stumps, living trunk bases, living trunks, and root swellings. The rarest species of the genus Ganoderma are G. pfeifferi and G. valesiacum. G. pfeifferi grows mainly on Fagus sylvatica. It was recorded in the same numbers on the stumps and bases of living trunks. In the urban areas, surprisingly, we also recorded the typical forest species G. valesiacum on the living trunk of Larix sp.

Acknowledgments

This work has been supported by grants from the Scientific Grant Agency of the Ministry of Education, Science, Research and Sport of the Slovak Republic (VEGA No. 1/0286/17 and KEGA No. 025UMB-4/2017). We wish to acknowledge the anonymous reviewers for his/her detailed and helpful comments of the manuscript.

Antonín, V. (2006). Encyklopedie hub a lišejníků. Praha: Academia. [In Czech]

References

Bernicchia, A. (2005). Polyporaceae s.l. Fungi Europaei. Alassio: Massimo Candusso. [In Italian/English]

Boleková, L., Sliacka, I. (2015). Mikroskopická analýza spór lesklokôroviek Ganoderma spp. zaznamenaných v urbanizovanom prostredí. Acta Facultatis Ecologiae, 32, 13-21. [In Slovak]

Breitenbach, J., Kränzlin, F. (1986). Fungi of Switzerland. Non gilled fungi. Heterobasidiomycetes, Aphyllophorales, Gastromycetes. Lucerne: Mykologia Verlag.

Cooper, J., Kirk, P. (2017). CABI Bioscience Database, Landscape Research, Index Fungorum Database. http://www.speciesfungorum.org/Names/Names.asp

Gáper, J. (1998). Trúdniky na území Slovenska a ich šírenie v ekosystémoch bazídiospórami. Zvolen: Technická Univerzita vo Zvolene. [In Slovak]

Gáperová, S. (2001). Synantropné druhy v rode Ganoderma. Acta Facultatis Ecologiae, 8, 93-98. [In Slovak]

Gáperová, S., Krátka, E. (2002). História a d’alšie perspektívy databanky trúdnikov na Slovensku. Spravodajca Slovenskej Mykologickej Spoločnosti, 27, 15. [In Slovak]

Gáperová, S., Krátka, E. (2003). Databáza infikovaných introdukovaných drevín Slovenska na príklade najviac infikovanej dreviny. In: S. Bernadovičová (ed.), Dreviny vo verejnej zeleni: zborník z konferencie s medzinárodnou účastou (27-28.05.2003). Košice: Univerzita Pavla Jozefa Šafárika, 130-136. [In Slovak] 
Gašparcová, T., Gáper, J., Gáperová, S. (2017a). Väzba lesklokôroviek na druhy drevín na Slovensku. In: Z. Sitková, P. Pavlenda (eds.), Dlhodobý ekologický výskum a monitoring lesov: súčasné poznatky a výzvy do budúcnosti. Zvolen: Národné lesnícke centrum - Lesnícky výskumný ústav Zvolen, 49-53. [In Slovak]

Gašparcová, T., Gáper, J., Pristaš, P., Kvasnová, S., Gáperová, S. (2017b). Porovnanie ITS-PCR-RFLP a MALDI-TOF MS metód pri identifikácii drevoznehodnocujúcich húb z rodu Ganoderma. Chemické listy, 111(6), 388-391. [In Slovak]

Holec, J., Bielich, A., Beran, M. (2012). Přehled hub Střední Evropy. Praha: Academia.

Karadelev, M., Rusevska, K., Kajevska, I. (2008). Distribution and ecology of genus Ganoderma (Ganodermataceae) in the republic of Macedonia. In: D. Kule, I. Malollari, D. Haxhimihali, A. Çullaj, A. Miho, F. Babani, D. Dhora, S. Shumka, B. Mustafa, P. Abeshi, R. Oelmüller, F. Macchia, R. Bachofen, L. Melofski, F. Vosniakos, P. Samaras (eds.), Proceedings of International Conference on Biological and Environmental Sciences. Tirana: FNS Tirana University, 320-326.

Kotlaba, F. (1984). Zeměpisné rozšiření a ekologie chorošů /Polyporales s.l./ v Československu. Praha: Academia. [In Czech]

Kotlaba, F., Pouzar, Z. (2009a). Ekologie choroše lesklokorky tmavé - Ganoderma adspersum - v Čechách. Mykologické Listy, 109, 11-15. [In Czech]

Kotlaba, F., Pouzar, Z. (2009b). Ekologie lesklokorky pryskyřičnaté - Ganoderma resinaceum - a její šírení v Čechách. Mykologické Listy, 107, 14-19. [In Czech]

Krátka, E., Gáperová, S., Hlásny, T. (2004). Databáza drevokazných húb Slovenska a možnosti jej spracovania v GIS. In: P. Hlaváč (ed.), Nové trendy v ochrane lesa a krajiny. Zvolen: Technická Univerzita vo Zvolene, 393. [In Slovak]

Marhold, K., Hindák, F. (1998). Zoznam vy̌š̌ich a nižších rastlín Slovenska. Bratislava: VEDA. [In Slovak]

Moncalvo, J.M. (2000). Systematics of Ganoderma. In: J. Flood, P.D. Bridge, M. Holderness (eds.), Ganoderma Diseases of Perennial Crops. Wallingford: CAB International, 23-45.

Papp, V., Szabó, I. (2013). Distribution and host preference of poroid Basidiomycetes in Hungary I. Ganoderma. Acta Silvatica et Lignaria Hungarica, 9, 71-83. DOI: 10.2478/aslh-2013-0006

Plank, S., Wolkinger, F. (1981). Holzabbauende Pilze an der Waldgrenze im Lachtal (Steiermark, Niedere Tauren). Mitteilungen des Naturwissenschaftlichen Vereines für Steiermark, 111, 137-142. [In German]

Pristaš, P., Gáperová, S., (2001). K možnostiam využitia metódy PCR v mykológii. In: Š. Čikoš, J. Koppel, M. Kantíková (eds.), Polymerázová retazová reakcia a jej použitie v biologickom výskume a diagnostike. Košice: Ústav Fyziológie Hospodárskych Zvierat SAV, 158-163. [In Slovak]

Pristaš, P., Kvasnová, S., Gáperová, S., Gašparcová, T., Gáper, J. (2017). Application of MALDI-TOF mass spectrometry for in-vitro identification of wood decay polypores. Forest Pathology, e12352. DOI: 10.1111/efp. 12352

Richter, Ch., Wittstein, K., Kirk, P.M., Stadler, M. (2015). An assessment of the taxonomy and chemotaxonomy of Ganoderma. Fungal Diversity, 71, 1-15. DOI 10.1007/s13225-014-0313-6

Ryvarden, L. (1991). Genera of polypores. Nomenclature and taxonomy. Oslo: Fungiflora.

Ryvarden, L., Gilbertson, R.L. (1993). European polypores. Part 1. Oslo: Fungiflora.

Ryvarden, L., Melo, I. (2014). Poroid fungi of Europe. Oslo: Fungiflora.

Schwarze, F.W.M.R., Ferner, D. (2003). Ganoderma on trees - differentiation of species and studies of invasiveness. Arboricultural Journal: The International Journal of Urban Forestry, 27, 59-77. DOI: $10.1080 / 03071375.2003 .9747362$

Sokół, S. (2000). Ganodermataceae Polski: Taksonomia, ekologia i rozmieszczenie. Katowice: Wydawnictwo Uniwersytetu Śląskiego. [In Polish] 
Szczepkowski, A., Konsencjusz, M. (2006). The intensity of wood decay caused by Ganoderma pfeifferi Bres., and the influence of temperature on growth of its mycelia in laboratory conditions. Forestry and Wood Technology, 60, 65-73.

The International Plant Names Index (2012). http://www.ipni.org.

Tortić, M. (1985). Distribution of Polypores in Yugoslavia. II Ganoderma. Acta Botanica Croatica, 44, $59-71$

Zhou, L.W., Cao, Y., Wu, S.H., Vlasák, J., Li, D.W., Li, M.J., Dai, Y.Ch. (2015). Global diversity of the Ganoderma lucidum complex (Ganodermataceae, Polyporales) inferred from morphology and multilocus phylogeny. Phytochemistry, 114, 7-15. DOI: 10.1016/j.phytochem.2014.09.023 
Appendix 1

Tab. 1. Host preferences of species of the genus Ganoderma

\begin{tabular}{|c|c|c|c|}
\hline $\begin{array}{l}\text { Species of the genus } \\
\text { Ganoderma }\end{array}$ & $\begin{array}{c}\text { Total number } \\
\text { of records }\end{array}$ & Woody plant taxa & $\begin{array}{c}\text { Number of } \\
\text { records }\end{array}$ \\
\hline \multirow{29}{*}{ Ganoderma adspersum } & \multirow{29}{*}{102} & Abies sp. & 1 \\
\hline & & Acer platanoides L. & 1 \\
\hline & & A. pseudoplatanus L. & 3 \\
\hline & & Aesculus hippocastanum L. & 18 \\
\hline & & Armeniaca vulgaris Lam. & 1 \\
\hline & & Celtis occidentalis L. & 1 \\
\hline & & Cerasus avium (L.) Moench & 2 \\
\hline & & Crataegus laevigata (Poir.) DC & 1 \\
\hline & & Fagus sylvatica L. & 2 \\
\hline & & Fraxinus excelsior $\mathrm{L}$. & 7 \\
\hline & & Gleditsia triacanthos L. & 8 \\
\hline & & Juglans regia $\mathrm{L}$. & 2 \\
\hline & & Larix sp. & 1 \\
\hline & & Morus nigra L. & 2 \\
\hline & & Negundo aceroides Moench & 1 \\
\hline & & Picea abies (L.) P. Karst. & 3 \\
\hline & & Populus alba L. & 2 \\
\hline & & P. nigra L. & 3 \\
\hline & & Prunus serrulata Lindl. & 3 \\
\hline & & Quercus petraea (Matt.) Liebl. & 2 \\
\hline & & Quercus sp. & 2 \\
\hline & & Robinia pseudoacacia L. & 3 \\
\hline & & Salix caprea L. & 1 \\
\hline & & Sorbus aucuparia L. & 2 \\
\hline & & Spirea veitschii Hemsl. & 1 \\
\hline & & Tilia cordata Mill. & 17 \\
\hline & & Tilia sp. & 1 \\
\hline & & T. platyphyllos Scop. & 2 \\
\hline & & unidentified & 9 \\
\hline \multirow{10}{*}{ Ganoderma applanatum } & \multirow{10}{*}{64} & Abies sp. & 1 \\
\hline & & Acer pseudoplatanus L. & 1 \\
\hline & & Alnus glutinosa (L.) Gaertn. & 1 \\
\hline & & Carpinus betulus L. & 2 \\
\hline & & Cerasus avium (L.) Moench & 3 \\
\hline & & Fagus sp. & 4 \\
\hline & & Fagus sylvatica L. & 2 \\
\hline & & Fraxinus excelsior L. & 1 \\
\hline & & Fraxinus sp. & 1 \\
\hline & & Negundo aceroides L. & 1 \\
\hline
\end{tabular}


Picea abies (L.) Karst. $\quad 1$

Populus alba L. 2

P. nigra L. 1

Populus sp. 1

P. tremula L. 2

Prunus domestica $\mathrm{L}$. $\quad 1$

Prunus sp. 1

Quercus robur $\mathrm{L}$. 3

$\begin{array}{lll}\text { Ganoderma applanatum } & \text { Quercus sp. }\end{array}$

Robinia pseudoacacia L. $\quad 4$

Salix caprea L. 2

S. fragilis L. $\quad 1$

Salix sp. 2

Tilia cordata Mill. $\quad 1$

T. platyphyllos Scop. $\quad 1$

Tilia sp. 2

unidentified 20

Abies alba Mill. 1

Alnus glutinosa (L.) Gaertn. $\quad 1$

Larix sp. 1

Ganoderma carnosum

11

Quercus sp. $\quad 1$

Tilia sp. 1

unidentified 6

Alnus sp. 1

A. glutinosa (L.) Gaertn. 1

Armeniaca vulgaris Lam. $\quad 1$

Ganoderma lucidum $\quad 37 \quad$ Carpinus betulus L. 2

Carpinus sp. 1

Castaneae sativa Mill. $\quad 1$

Quercus sp. 6

unidentified 24

Ganoderma pfeifferi

4 Acer platanoides $\mathrm{L}$.

1

Fagus sylvatica $\mathrm{L}$. 2

Tillia platyphyllos Scop 1 


\begin{tabular}{llc}
\hline & Acer campestre L. & 1 \\
& A. platanoides L. & 1 \\
& A.pseudoplatanus L. & 1 \\
& Aesculus hippocastanum L. & 4 \\
& Celtis occidentalis L. & 2 \\
& Fagus sylvatica L. & 1 \\
& Fraxinus excelsior L. & 2 \\
& Gleditsia triacanthos L. & 5 \\
& Juglans regia L. & 1 \\
& Negundo aceroides Moench & 1 \\
& Populus sp. & 1 \\
& Quercus cerris L. & 10 \\
& Q. robur L. & 4 \\
& Quercus sp. & 1 \\
& Robinia pseudoacacia L. & 5 \\
& Salix alba L. & 1 \\
& Sophora japonica L. & 1 \\
& unidentified & 2 \\
\hline Ganoderma valesiacum & Larix sp. & 1 \\
\hline
\end{tabular}


Ganoderma (Basidiomycota, Polyporales) is a cosmopolitan genus with the greatest diversity in the tropics. It causes white rot of a wide range of woody plants all over the world. In Europe, 7 species of the genus Ganoderma grow: Ganoderma adspersum, G. applanatum, G. carnosum, G. lucidum, G. pfeifferi, G. resinaceum and G. valesiacum. All of them also occur in Slovakia. The aim of the present study was to identify the presence of Ganoderma species in the urban areas of Slovakia and to find out their host preferences and the topology of the basidiocarps on the colonised trees. A total 263 findings of Ganoderma obtained by our own field research and the processing of records from herbarium items located in natural museums in Bratislava (Slovakia) and Prague (Czechia) were analysed to detect their ecological characteristics. The occurrence of all 7 Ganoderma species was recorded in the urban areas of Slovakia. The most common species is G. adspersum (39\% of all records) with the widest range of host woody plants (24 species). G. applanatum is the second most widespread species in the urban areas of Slovakia growing mostly on a decomposing wood of unknown trees ( $31 \%$ of all findings) and also on beeches ( $9 \%$ of all findings). G. resinaceum is the third most widespread in the urban areas, and it grew mainly on Quercus. G. lucidum was most often found on unknown trees (65\% of all findings) and also on oaks (16\% of all findings). The rarest Ganoderma species are G. valesiacum (only 1 record on Larix sp.), G. pfeifferi (4 records, mainly on Fagus sylvatica), and G. carnosum ( $4 \%$ of all records, mainly on a decomposing wood of unknown trees).

Key words: Ganoderma, polyporoid fungi, basidiomata, host tree, wood-decaying fungi

Received: [2018.03.02]

Accepted: [2018.09.24]

\section{Żywicielskie preferencje grzybów z rodzaju Ganoderma rozkładających drewno w środowisku miejskim na Słowacji \\ Streszczenie}

Lakownica - Ganoderma P. Karst. (Basidiomycota, Polyporales) to kosmopolityczny rodzaj o największej różnorodności w tropikach. Lakownice powodują białe zgnilizny wielu różnych drzewostanów na całym świecie. W Europie, w tym także na Słowacji, występuje siedem gatunków lakownic: Ganoderma adspersum (1. europejska), G. applanatum (1. spłaszczona), G. carnosum (l. brązowoczarna), G. lucidum (l. zółtawa), G. pfeifferi (l. czerwonawa), G. resinaceum (1. jasnomiąższowa) oraz G. valesiacum (l. walezyjska). Celem niniejszych badań było zidentyfikowanie obecności poszczególnych gatunków lakownic w zurbanizowanym środowisku Słowacji oraz określenie ich preferencji żywicielskich, a także topologii bazydiokarpów na skolonizowanych drzewach. W badaniu wykorzystano 263 okazy lakownic zebranych w trakcie badań terenowych oraz oznaczonych rekordów, pochodzących ze zbiorów zielnikowych z muzeów przyrodniczych w Bratysławie (Słowacja) oraz w Pradze (Czechy). W zurbanizowanym środowisku Słowacji odnotowano występowanie wszystkich 7 gatunków lakownic. Najczęściej notowywanym gatunkiem jest G. adspersum (39\% wszystkich rekordów), z najszerszym spektrum drzew żywicielskich (24 gatunki). G. applanatum jest drugą najbardziej rozpowszechnioną lakownicą w zurbanizowanycm środowisku na Słowacji. Rośnie głównie na rozkładającym się drewnie nieidentyfikowalnych gatunków drzew (31\% wszystkich rekordów), a także na bukach (9\% wszystkich rekordów). G. resinaceum jest trzecim najbardziej rozpowszechnionym gatunkiem i rośnie głównie na dębach. Natomiast G. lucidum zazwyczaj występowała na nieidentyfikowalnym drewnie (65\% wszystkich rekordów) oraz na dębach (16\% wszystkich rekordów). Najrzadsze lakownice to: G. valesiacum (tylko jedno znalezisko na Larix sp.), G. pfeifferi (4 rekordy, głównie na Fagus sylvatica) oraz G. carnosum (4\% wszystkich rekordów, zwłaszcza na nieidentyfikowalnym gatunkowo rozkładającym się drewnie).

Słowa kluczowe: Ganoderma, grzyby polyporowe, basidiomaty, drewno żywicielskie, grzyby rozkładające drewno 


\section{Information on the authors}

Terézia Beck https://orcid.org/0000-0002-3179-8380

She is an internal PhD student at Faculty of Natural Sciences of Matej Bel University in Banská Bystrica (Slovakia), Department of Biology and Ecology, in study program „Evolution of ecosystems and their protection”. The topic of her dissertation is „Diversity and distribution of the genus Ganoderma in Slovakia".

\section{Ján Gáper}

He is the member of Department of Biology and General Ecology of Faculty of Ecology and Environmental Sciences of Technical University in Zvolen as well as the member of Department of Biology and Ecology of Faculty of Natural Sciences of University of Ostrava in Ostrava. He is interested in the identification and ecology of wood-decaying polypores, regarding the importance for ecosystem functioning.

\section{Martin Šebesta}

$\mathrm{He}$ is an internal PhD student at Faculty of Ecology and Environmental Sciences of Technical University in Zvolen (Slovakia), Department of Biology and General Ecology, in study program "Ecology and Biodiversity Conservation". The topic of his dissertation is "Diversity and ecology of wood-decay polypores in the urban environment".

\section{Svetlana Gáperová}

She is the member of Department of Biology and Ecology of Faculty of Natural Sciences of Matej Bel University in Banská Bystrica. She is interested in the biology and ecology of both woody plants and wood-decaying fungi in urban areas and monitoring of urban air pollution. 